\title{
4
}

\section{What should copyright protect?}

\author{
R Anthony Reese
}

\section{Introduction}

This project aims to imagine what copyright law might look like if it were designed anew, from scratch. In Chapter 1, the editors ask what it would look like if we could 'design a law to encourage creativity, remunerate and support creators, and increase the size of cultural markets to ensure broad access to new knowledge and creativity'. ${ }^{1}$ These goals seem to me to reflect the 'preponderance of individual interests' approach to the public interest that the editors have described. ${ }^{2}$ After all, virtually every member of society is a creator - for example, in the age of cell phones, almost all of us take photographs. And almost all of us enjoy access to some informational and/or cultural products. Again, to take a simple and widespread example, virtually all of us sing or hum other people's songs (perhaps in the shower, or to our beloved), or tell jokes we have heard from other people. These dual roles as creator and enjoyer of informational and cultural products undergird each individual's interest in the copyright system, and result in what the

1 Rebecca Giblin and Kimberlee Weatherall, 'If we redesigned copyright from scratch, what might it look like?', this volume, [1].

2 Giblin and Weatherall, above $\mathrm{n} 1,[10]-[11]$. 
editors describe as our 'shared interest in encouraging and supporting creativity[,] in recognising the rights and interests of creators, in a rich and accessible culture, and in technological and economic progress. ${ }^{3}$

An early task in reimagining a redesigned copyright law that seeks to achieve those goals will be defining which kinds of creativity this copyright law will encourage, which creators it will protect and support, and which informational and cultural products will come within its ambit. In recent years, current law has repeatedly faced questions about what material copyright protects. Is an artistically planted flowerbed a copyrightable work $?^{4}$ What about a yoga pose, or a series of such poses? $?^{5}$ Or a genetically modified fish $?^{6}$ Can a perfume be protected by copyright? ${ }^{7}$ Can a sporting event? ${ }^{8}$ While a motion picture can be copyrighted under current law, is an actor's five-second performance in a film itself protected as a copyrighted work $?^{9}$ Is a list of names and phone numbers of everyone in a particular geographic locality, organised alphabetically by surname, copyrightable? ${ }^{10}$ The answers given to these questions have not always been consistent or convincing. A reimagined copyright system must address these questions and, ideally, provide a framework for answering the additional questions about the availability of copyright protection that will inevitably arise going forward.

3 Giblin and Weatherall, above n 1, [19] (emphasis added).

4 See Kelleyv Chicago Park District, 635 F 3d 290 ( $7^{\text {th }}$ Cir, 2011).

$5 \quad$ See Bikram's Yoga College of India LP v Evolation Yoga LLC, 803 F 3d 1032 (9 $9^{\text {th }}$ Cir, 2015); Copyright Office, Registration of Claims to Copyright, 77 Fed Reg 37,605 (22 June 2012).

6 US Copyright Office, Re: GloFish Red Zebra Danio Glowing in Artificial Sunlight (5 September 2013) <ipmall.law.unh.edu/sites/default/files/hosted_resources/CopyrightAppeals/2013/GloFish RedZebraDanioGlowing.pdf > (rejecting copyright claim in 'a living Red Zebra Danio fish that the Applicant has genetically altered so that the fish "fluoresces" when it is exposed to artificial light').

7 See Kamiel Koelman, Copyright in the Courts: Perfume as Artistic Expression?, (2006) September WIPO Magazine; see also Charles Cronin, Genius in a Bottle: Perfume, Copyright, and Human Perception, (2009) 56 Journal of the Copyright Society of the USA 427; Thomas G Field, Jr, Copyright Protection for Perfumes, 45 (2004) IDEA: The Journal of Law and Technology, 19.

8 See Premier League Ltd $v$ QC Leisure, (C-403/08 and C-429/08 (joined cases)) [2011] ECR-I-9083; National Basketball Association v Motorola Inc, 105 F 3d 841 (2 $\left.{ }^{\text {nd }} \mathrm{Cir}, 1997\right)$. See also Instituut voor Informatierecht (IViR), Study on sports organisers' rights in the European Union: Final Report, 29-30 (2014).

$9 \quad$ Garcia $v$ Google Inc, 786 F 3d 733 (9 $9^{\text {th }}$ Cir, 2015) (en banc), superseding 766 F 3d 929 $\left(9^{\text {th }}\right.$ Cir, 2014).

10 Feist Publications Inc v Rural Telephone Service Co Inc, 499 US 340 (1991); Telstra Corporation Limited v Phone Directories Company Pty Ltd [2010] FCAFC 149. 
The question of what copyright protects has at least two components. ${ }^{11}$ The first issue is which type of material copyright will cover - that is, what is the subject matter of copyright law? Defining copyright's subject matter results in including and excluding entire categories of material from protection. So, for example, someone who breeds a new flower will not be able to obtain copyright protection for that flower if plants are not within copyright's subject matter, but the breeder's photograph of one of her new flowers in bloom will be eligible for copyright protection if photographs are within copyright's subject matter. The second issue concerns any particular item within copyright's subject matter for which protection is sought. Simply falling within copyright's subject matter is not enough - the item in which copyright is claimed must also meet copyright's standards in order to actually qualify for protection. So, for example, while paintings are within the subject matter of copyright, ${ }^{12}$ a painting of one of the new flowers will be protected only if it meets the law's requirements, such as being independently created by the painter and embodying minimal creativity (or, in another formulation, being the painter's 'own intellectual creation'). Figuring out what a reimagined copyright law should protect involves defining both copyright's subject matter and the standards required for protection.

The fundamental public interest aims identified in Chapter 1 do not offer much direct guidance on the questions of subject matter and standards. The reimagined copyright system may aim to provide incentives for the production of creative works, to enable creators to obtain a fair return on their creative works, and to promote the preservation and dissemination of creative works that make up our cultural heritage. But these aims do not tell us which creative works we want to promote, reward and preserve, or just how creative those works should be.

11 A potential third component of the question is the scope of protection granted to any item that comes within copyright's subject matter and meets the standards for protection. This chapter largely does not take up that aspect of a reimagined copyright law.

12 At least for any copyright system that complies with the obligations of the Berne Convention (Berne Convention for the Protection of Literary and Artistic Works, opened for signature 9 September 1886 (amended in 1914, 1928, 1948, 1967, 1971, and 1979) 25 UST 1341, 828 UNTS 221, entered into force 5 December 1887). 
Determining what a reimagined copyright system would protect is important for at least two reasons. First, the decision has significant implications for all other aspects of copyright law. The articulations of copyrightable subject matter and of the standards for protection serve as the gatekeepers for copyrightability. The wider the gate is opened, the more - and more varied - will be the creations that are copyrightable.

To the extent that this volume's project is to try to design a copyright system from scratch, how broadly the scope of copyright's subject matter should extend, and what standards for protection the law should impose, depends to some degree on other elements of the redesigned copyright system. Take the question of whether the text of an entirely ordinary short and routine email message should qualify for copyright protection. If qualifying for copyright gives the writer of the message a robust set of rights to exclude others for a very long period of time $^{13}$ with generous remedies against infringers ${ }^{14}$ and no obligation to comply with any formalities, ${ }^{15}$ then the public might well want copyright law to impose a relatively demanding standard of creativity for a work to receive protection. In such instances, the public does not seem well served by granting copyrights that would potentially give the copyright owner broad power to interfere with other people's expression - even when they draw on the original writer's expression. On the other hand, if the email qualifies for a copyright that includes narrower exclusionary rights that last for a relatively short term, and only if the email's author complies with useful formalities, then the public might not be particularly concerned that the writer could receive copyright protection even though her product displays very little creativity.

While the chapters elsewhere in this volume address many of those other aspects of a redesigned copyright system, in this chapter I do not attempt to imagine how to calibrate copyright's subject matter and standards to all of the possible permutations of these other aspects. Instead, I assume for purposes of argument that the other aspects

13 See Rebecca Giblin, 'Reimagining copyright's duration', this volume.

14 See Kimberlee Weatherall, 'A reimagined approach to copyright enforcement from a regulator's perspective', this volume.

15 See Dev S Gangjee, 'Copyright formalities: A return to registration?', this volume. 
of copyright law would remain largely as they are today, and then attempt to rethink the questions of subject matter and standards for protection in light of the current system.

Second, the decision of what copyright law will protect reflects the principles animating the purpose of copyright itself. In the instrumentalist view, ${ }^{16}$ the decision embodies an answer to the question of which products of human creativity society determines that the law needs to protect against copying so that creators will produce those products at the level that society wants and will be rewarded for doing so. Determining the 'optimal' level of production of any particular product of human creativity may be an insoluble empirical question. It may well be possible, though, for a society to decide that the populace would prefer, in comparison to current levels, to have a greater, a lower, or about the same level of production of certain creative products, and copyright law could reflect that decision. On the naturalist view, decisions about protectability reflect determinations of desert - specifically, whether the author has produced the kind of creation that deserves the kind of protection offered by copyright law.

In this chapter, my primary aim is not to produce a complete enumeration of what particular subject matter copyright law should protect or a complete articulation of the standards any item of protectable subject matter should have to meet in order to actually acquire copyright protection. Instead, with respect to subject matter, I focus largely on how a reimagined copyright system should articulate what is and is not protected, rather than identifying what should be protected. With respect to standards for protectability, I suggest four specific areas in which imposing a standard in order for a creation to achieve copyright protection would seem justified, though for the most part I do not seek to identify detailed standards in these four areas.

16 Throughout this chapter, I use the terms 'instrumentalist' and 'naturalist' in the sense they are explicated in Chapter 1 . 


\section{Subject matter}

\subsection{Defining what copyright's subject matter includes}

\subsubsection{The need to define subject matter boundaries}

A copyright system demands some identification of the universe of material to which copyright law does and does not apply. At the very least, such boundary definition is necessary to separate the legal regime governing copyright from other legal regimes that govern different types of subject matter, such as land, tangible personal property, financial instruments, bodily organs and so forth.

At the most basic level, copyright protection might be thought to extend to any product of human creativity. Copyright's fundamental impetus, after all, as identified in the goals discussed above, is to spur and reward human creativity. In the instrumentalist view, copyright does this by granting the creator enforceable rights to exclude others from using her creation in order to give the author (and those who assist her in disseminating that creation) the opportunity to earn a return on the resources they have invested in it. In the naturalist view, copyright does this by recognising the creator's rights to control the products of her creativity. Perhaps, then, copyright's subject matter boundaries should be defined simply by reference to human creativity, so that if something is a product of human creativity it could be protected by copyright. ${ }^{17}$

Granting copyright to any product of human creativity, though, would produce a copyright law with overly broad coverage. First, the law's coverage would overlap with other legal regimes. For example, many inventions that are subject to patent protection result from human creativity, but it is hard to see how the public would benefit by protecting those inventions by copyright law instead of, or in addition to, protecting them by patent law. The standards for protection, the rights granted, the term length, and many other features of the

17 See Christophe Geiger, 'Copyright as an access right: Securing cultural participation through the protection of creators' interests', this volume. 
copyright regime are ill-suited for a system governing the kinds of industrial property traditionally protected under patent law, even though those inventions are usually the products of human creativity.

In addition, extending copyright to all products of human creativity would bring within copyright's subject matter a wide variety of those products that have traditionally (though not necessarily universally) not been eligible for copyright protection. A partial list of such creative products would include yoga poses and sequences of yoga poses $;{ }^{18}$ artistically planted flower beds, ${ }^{19}$ and garden or landscape design more generally (including, for example, the design of golf courses); ${ }^{20}$ new breeds of plants or animals; perfumes ${ }^{21}$ as well as digital recordings of smells, ${ }^{22}$ culinary dishes, or perhaps the particular set of dishes available on a particular restaurant's menu, ${ }^{23}$ particular varieties of created food products such as beer, wine or cheese; fireworks displays $;{ }^{24}$ typography; ${ }^{25}$ clothing and other fashion design; tactile enhancements to books, ${ }^{26}$ sports plays or routines,

18 See e.g. Bikram's Yoga College of India LP v Evolation Yoga LLC, 803 F 3d 1032 (9 $9^{\text {th }}$ Cir, 2015); Copyright Office, Registration of Claims to Copyright, 77 Fed Reg 37,605 (2012).

19 See e.g. Kelley v Chicago Park District, 635 F 3d 290 ( $7^{\text {th }}$ Cir, 2011).

20 Cf Pebble Beach Co v Tour 18 I Ltd, 155 F 3d 526 ( $5^{\text {th }}$ Cir, 1998) (finding trade dress protection in appearance of golf holes).

21 See Koelman, above n 7; see also Cronin, above n 7; Field, above $n$.

22 See e.g. Stephen Williams, 'Plug-and-Play Aromas at Your Keyboard', NY Times (online), 20 January 2011; William Grimes, 'Now on the PC Screen: Scent of a Kitchen', NY Times (online), 13 September 2000, F1; Charles Platt, 'You've Got Smell!', Wired (online), November 1999.

23 See e.g. Christopher J Buccafusco, 'On the Legal Consequences of Sauces: Should Thomas Keller's Recipes Be Per Se Copyrightable?' (2007) 24 Cardozo Arts and Entertainment Law Journal 1121; Caroline Reebs, 'Sweet or Sour: Extending Copyright Protection to Food Art' (2011) 22 DePaul Journal of Art, Technology \& Intellectual Property Law 41. See also Kim Seng Co v J \& A Importers Inc, $810 \mathrm{~F}$ Supp 2d 1046 (CD Cal 2011) (claiming protection on a traditional Vietnamese dish of a bowl of rice sticks topped with egg rolls, grilled meat, and assorted garnishes as a 'food sculpture'). Note that the 'sculptural' (or pictorial, in the case of, for example, decorated cakes or cookies) aspects of the presentation of a particular culinary dish might be protectable under current copyright law in many jurisdictions.

24 See Bobby Kerlik, 'Judge tosses lawsuit between fireworks rivals Zambelli, Pyrotecnico', Pittsburgh Tribune-Review (online), 11 November 2010, <www.pittsburghlive.com/x/ pittsburghtrib/news/pittsburgh/s_708880.html> (site discontinued) (reporting on dispute over alleged violation of non-compete clause when employee of one fireworks company left to work for a rival company).

25 See Robert A Gorman, Jane C Ginsburg, and R Anthony Reese, Copyright: Cases \& Materials (Foundation Press, $8^{\text {th }}$ ed, 2011) 250-252.

26 See e.g. Elise Hu, 'Sensory Fiction: Books That Let You Feel What The Characters Do', NPR All Tech Considered (6 February 2014), <www.npr.org/blogs/alltechconsider ed/2014/02/06/272044748/sensory-fiction-books-that-let-you-feel-what-the-characters-do $>$. 
or even sporting events, ${ }^{27}$ parades ${ }^{28}$ amusement park rides (such as rollercoasters); body parts altered by cosmetic surgery; $;^{29}$ the patterns of liquid created by fountains; ${ }^{30}$ the arrangement and positioning of objects and people to be photographed; ${ }^{31}$ and invented languages. ${ }^{32}$ It is not clear that a preponderance of citizens would want a significantly greater level of production of all of these types of creative works than we currently have, or would want that greater production enough to grant exclusive rights in all of these products of creativity. At the very least, experience to date does not suggest that society suffers from a serious deficit in production of these creations because they lack the possibility of obtaining reward by means of copyright protection. Nor does there appear to be a social consensus that those who create these types of products of human creativity deserve the protection as 'authors' that has so far largely been withheld from them.

A reimagined copyright regime that would automatically offer protection to all products of human creativity would thus seem to recognise copyrightable subject matter more broadly than the identified goals for the regime would justify. As discussed below, human creativity may be necessary to produce a copyrightable work, but the fact that a creation is a product of human creativity is likely not sufficient to justify protecting that creation by copyright. Many products of human creativity seem likely to lie outside the scope of a copyright system designed to further the public interest. At the very least, it seems impossible to say that the public interest would be best served by making all of these products protectable by copyright based merely on the fact that they can be described as products of

27 See e.g. Premier League Ltd $v$ QC Leisure, (C-403/08 and C-429/08 (joined cases)) [2011] ECR-I-9083; National Basketball Association v Motorola Inc, $105 \mathrm{~F} 3 \mathrm{~d} 841$ ( $\left.2^{\text {nd }} \mathrm{Cir}, 1997\right)$. See also IViR, Study on sports organisers' rights in the European Union: Final Report (2014) 29-30.

28 See e.g. Production Contractors Inc $v$ WGN Continental Broadcasting Co, 622 F Supp 1500 (ND Ill 1985).

29 See e.g. Guy Trebay, 'The Man Behind the Face', NY Times (New York), 30 March 2014, ST 1, 15, 17 (Dr Frederic Brandt, cosmetic dermatologist, noted that 'I approach each face with a visual perception, an artistic perception and a medical perception') (emphasis added).

30 See e.g. In re Hruby, 373 F 2d 997 (CCPA 1967) (holding design of fountain spray to be an 'article of manufacture' subject to design patent protection).

31 See e.g. Creation Records Ltd and Others v News Group Newspapers Ltd, [1997] EWHC (Ch) 370 .

32 See e.g. SAS Institute Inc $v$ World Programming Ltd, [2013] EWHC (Ch) 69, [33]. See also Ben Hancock, 'Copyright Klingon? Not Quam Ghu'vam, IoD!', (2016) The Recorder (online), 28 April 28, 2016 (discussing litigation over claims of copyright in invented Klingon language from Star Trek works); Amy Chozick, 'Athhilezar? Watch Your Fantasy World Language', NY Times (New York), 12 December 2011, A1, A3. 
human creativity. Copyright law needs some further filter or filters to determine which products of human creativity should be subject to copyright protection.

\subsubsection{Subject matter boundaries should be defined legislatively ${ }^{33}$}

I do not propose in this chapter to attempt to identify the precise boundaries of which products of human creativity should and should not be subject to copyright protection. The decision whether to protect any particular type of work will depend on fact-specific questions, involving the issue of whether copyright protection for that particular type of work will, overall, advance the public interest or not. Whether copyright protection for a particular kind of subject matter will advance the public interest may well change over time ${ }^{34}$ making it impossible to define in the abstract a complete list of which types of work copyright should protect. This is particularly true given that technological developments will likely create hitherto unknown forms of creative expression, and that views of what constitutes 'creativity' or 'authorship' are likely to evolve over time.

Weighing the costs and benefits of extending copyright protection to any particular form of human creativity requires deliberation and an affirmative decision about the ultimate desirability of extending protection. That deliberation and decision ought to rest with the political organ that embodies the broadest representation of the public and its interests, which means that the decision should be legislative, rather than administrative or judicial. Indeed, a basic principle of a reimagined copyright system should be that copyright law will protect particular types of creative products only after an affirmative decision that protection for such works will, on balance, sufficiently advance the public interest. That affirmative decision is essentially a policy choice, and in a copyright system that seeks to embody

33 This section draws significantly from $\mathrm{R}$ Anthony Reese, 'Copyrightable Subject Matter in the "Next Great Copyright Act"” (2014) 29 Berkeley Technology Law Journal 1489.

34 The Berne Convention's illustrative list of works has evolved over time, as have the protected categories enumerated in the US copyright statute. Sam Ricketson and Jane C Ginsburg, International Copyright and Neighbouring Rights: The Berne Convention and Beyond (Oxford University Press, $2^{\text {nd }}$ ed, 2006), vol 1, § 8.09, 409; Reese, above n 33, 1492-1496. 
the preponderance-of-interests goals identified above, such a choice should be made by the legislature as the most broadly representative lawmaking body.

Deciding whether to protect a particular form of human creativity implicates policy questions that the legislature is best equipped to evaluate. In an instrumentalist system, the fundamental question will be whether protection is needed to encourage greater production or dissemination and whether that need outweighs any costs that protection would impose. In a naturalist system, the fundamental question will be what qualifies as 'authorship' deserving of protection of author's rights.

A legislature is generally better positioned to answer those questions than is a court. ${ }^{35} \mathrm{~A}$ court would consider the question in the context of a live controversy over a particular creation, in which the creator would like to claim copyright in order to stop another party from copying the creation. This very context might lead a court, relying in part on intuitions about those who reap where they have not sown, to incline toward recognising the plaintiff's claimed creation as a product of human creativity within copyright's protection. ${ }^{36}$ But, as Benjamin Kaplan noted about copyright litigation generally, 'Our gaze should not be confined to this plaintiff and this defendant. If the contest is conceived as being thus restricted, a court out of understandable sympathy would be inclined to hold for the plaintiff whenever the defendant was shown to have made any recognizable use of the plaintiff's contribution. That would be a very mistaken attitude.

35 This is not to suggest that legislatures necessarily take advantage of their superior institutional capacity to gather the information needed to make these decisions. See e.g. Paul Goldstein and Bernt Hugenholtz, International Copyright (Oxford University Press, $2^{\text {nd }}$ ed, 2010) 19 ('While the ideal copyright legislator would, before voting to extend protection to new subject matter or rights, require a showing that the extension is needed as ancentive to continued investment, common law legislatures have in fact regularly, indeed mostly, extended copyright without any empirical showing that authors would produce, and publishers publish, fewer works if the extension were not given'). See also Geiger, above n 17, 105.

36 See Wendy J Gordon, 'On Owning Information: Intellectual Property and the Restitutionary Impulse' (1992) 78 Virginia Law Review 149, 151-156. Gordon suggests that a 'common law trend toward granting new intellectual property rights has been fueled' in part by 'an intuition of fairness - a norm often linked to natural rights - that one should not "reap where another has sown"', at 156. As Benjamin Kaplan pointed out, such an intuition on the part of a court may be at best incomplete: '[I]f man has any "natural" rights, not the least must be a right to imitate his fellows, and thus to reap where he has not sown.' Benjamin Kaplan, An Unhurried View of Copyright (Columbia University Press, 1967) 2. 
There is a further diffused public interest necessarily involved. ${ }^{37}$ That interest, in disputes over whether a particular type of creation is or is not copyrightable subject matter, is the decision of whether, as a category, such creations should be protected by copyright, aside from any sympathy for the particular plaintiff in the dispute before the court. And the litigation context tends not to provide the court with the information that would be useful in addressing that larger policy question: whether we need to protect those who produce and distribute this type of creation against unauthorised copying in order to generate the production and dissemination of a socially desirable amount and variety of these creations (or, in a naturalist system, whether the producers of these creations are 'authors' deserving of author's rights).

Not only is the legislature the appropriate site for making the policy choices involved in deciding whether to extend protection to any particular category of creative product, but the legislature also has better tools at its disposal to tailor any protection that it grants. In particular, the legislature can better account for notice and retroactivity concerns in granting protection and has more options with respect to calibrating the form and scope of any protection granted. ${ }^{38}$

For example, calibrating the scope of new protection for a type of authorial creation not previously protected could involve tailoring the exclusive rights and limitations applicable to that type of work, or granting protection for a relatively short term, or offering protection only on the condition of compliance with certain formalities. ${ }^{39}$ Or, after examining the issues surrounding a particular type of possible subject matter, the legislature might decide that this type of creative production does not need copyright protection, but that it should receive some more tailored, sui generis form of protection against copying. ${ }^{40}$ In considering whether to protect any particular new category of subject matter, the legislature has the power to

\footnotetext{
37 Kaplan, above n 36, at 76.

38 See Reese, above n 33, 1504-1508.

39 To the extent that international copyright treaties do not require a state to protect a particular type of creation, those treaties' obligations to grant a minimum term or not to impose formalities would not apply to any copyright protection granted to that type of creation. See e.g. Goldstein and Hugenholtz, above n 35, 220; Ricketson and Ginsburg, above n 34, 412.

40 See section 1.2.2, below.
} 
decide whether to bring that subject matter fully within the existing copyright regime, or whether to grant some other type of protection, which might, for example, last for a much shorter period of time or confer narrower rights. A court, on the other hand, faced with a claim seeking copyright protection for the same type of subject matter, would likely have a much more difficult time tailoring the scope or form of protection granted. As a result, a judicial decision recognising copyright protection to a form of expression not previously identified as copyrightable may overprotect a type of subject matter that the legislature would have found needed only a more tailored form of protection.

\subsubsection{How broadly or narrowly should copyright's subject matter be articulated?}

Once we accept that copyright should only protect some subset of the entire universe of products of human creativity, and that the legislature should decide which products come within that subset, we must decide how the legislature should articulate that subset in the copyright statute. In other words, what is the proper level of specificity with which a copyright statute should articulate the subject matter eligible for its protection? Perhaps not surprisingly, the best approach seems to lie somewhere between the broadest and most narrow possibilities.

\subsubsection{Broad articulation}

A broad approach might be for the copyright statute to extend protection to all productions of artistic creativity. Defining copyright's subject matter in this way should result in more narrow coverage than if copyright protected all products of human creativity. For example, this approach would presumably rule out copyright protection for most inventions thought of as protectable (if at all) by patent law, because even if such inventions are highly creative, they are unlikely to be artistically creative.

A statute that took this approach would require the courts and administrative authorities who implement the statute to determine what counts as 'artistic'. Making this determination should not involve judgments about the quality of artistic creativity in any particular work. Deciding whether a work is within the subject matter of copyright's protection would simply require determining 
whether works of this type are works of 'artistic' creativity. ${ }^{41}$ Once a determination has been made that a particular type of work - for example, photographs - is indeed a form of artistic creativity, all future works of that type would presumably be regarded as within the copyright law's subject matter. To the extent that 'artistic' creativity is viewed as superior to other types of creativity - and the fact that the law is granting copyright protection to artistic creativity and not other types of creativity already indicates a preferential status - it may be a disadvantage of this approach that it commits to judges and bureaucrats the value judgment of whether any particular type of creativity is artistic.

Articulating subject matter in this way would have flexibility: it would likely allow copyright's coverage to expand as views of what constitutes art evolve. ${ }^{42}$ For example, if creating a perfume, or a culinary dish, or even a variety of wine, came to be viewed as artistic endeavours, then a copyright statute that protected any work of artistic creativity would presumably apply to those products of artistic creativity without any need to amend the statutory definition of copyrightable subject matter. If the legislature has enacted a rule extending copyright to 'all products of artistic creativity', courts and administrative authorities could simply conclude that a form of human creativity that previously had not been understood as 'artistic' had come to be so understood and had therefore become subject to copyright protection.

Such an approach would not necessarily be in the public interest. The evolution of views on whether a type of creation is artistic might mean that society would desire to protect creations of that type by copyright. But just because a particular type of creation is regarded as 'artistic' does not necessarily mean that such artistic creations should get copyright protection.

41 As discussed below, some evaluation of the creativity embodied in the particular work may be necessary in order to determine whether that work, even if it comes within the subject matter of protection, meets the standards required to obtain protection, since a copyright system that seeks to further the public interest would likely extend protection only to works that embody some minimal authorial creativity.

42 Conversely, this approach might cause copyright's subject matter to contract if a form of expression once viewed as 'artistic" ceased to be viewed as artistic. 
The public interest would be better served by requiring deliberation about the desirability of protecting a form of creativity newly regarded as artistic and a specific affirmative decision to extend protection. As discussed in the preceding section, that deliberation and decision ought to rest with the social organ that embodies the broadest representation of the public and its interests. This suggests that the decision should be legislative, rather than administrative or judicial, and that therefore a very broad statutory articulation of copyright's subject matter may not sufficiently delineate which products of human creativity should receive copyright protection.

\subsubsection{Narrow articulation}

At the other end of the spectrum, the public interest in a copyright system that serves the goals identified above is likely not to be well served if copyright law articulates its subject matter with great specificity, particularly if the articulations are tethered to particular technologies. A reimagined copyright law will not work well if it does not protect new technological forms of embodying creativity that are very similar to existing forms of creativity that are already protected. For example, the type of creativity involved in a blog post does not differ substantially from that involved in a newspaper or magazine article. It is difficult to see why a copyright statute that protects periodical articles should not also protect blog posts without requiring the legislature to expressly amend the statute to do so.

Would extremely specific categories of protected subject matter be sufficiently flexible to accommodate new technological developments? They might be. For example, a copyright statute that protected 'newspapers and magazines' could be interpreted as extending protection to blog posts once the technology for blogs develops. After all, courts in both Britain and the United States interpreted the statutory term 'book' extremely broadly over the course of the eighteenth and nineteenth centuries, ${ }^{43}$ not limiting it to the conventional bound volume but instead interpreting it to include,

43 See e.g. Copyright Act of May 31 1790, ch 15, § 1, 1 Stat 124, 124 (repealed 1831) (protecting only books, maps and charts). See also Statute of Anne 1710, 8 Ann c 19 (England) (protecting only books). 
for example, single printed sheets. ${ }^{44}$ (The liberal construction had limits, however, as when courts refused to consider product labels as 'books' protected by the statute. $)^{45}$ Such an approach might mean that a blog would be deemed to be within a statutory category of 'newspapers and magazines', and therefore within the subject matter of copyright, once the technology for blogs develops.

But such broad interpretation of technologically specific articulations of statutory subject matter is not inevitable. For example, one might doubt whether a copyright statute that protected 'photographs and the negatives thereof' (as the US copyright statute did, beginning in $1865)^{46}$ would extend protection to products of digital photography, which does not, of course, involve negatives as part of its photographic process. The same question might have arisen in Great Britain under the provisions of the Copyright Act of 1911, which measured a photograph's term of protection 'from the making of the original negative from which the photograph was ... derived' and deemed the author of the work to be 'the person who was owner of such negative at the time when such negative was made' ${ }^{47}$ Those provisions might well have led to the conclusion that the 1911 Act would not protect a digital photograph, since that photograph would have no 'negative'.

Thus, a copyright statute that articulates protected subject matter using specific terms tethered to particular technologies will raise the risk (though not the certainty) that those terms will be construed too narrowly to include works, enabled by new technologies, that embody the same type of creativity as that embodied in types of works already expressly protected. But particularly in an era of rapid technological development such as ours, subjecting each new technological form

\footnotetext{
44 For examples of interpretations in US courts, see e.g. Clayton $v$ Stone, 5 F Cas 999 (CCSDNY 1829) (No 2,872); Drury v Ewing, 7 F Cas 1113 (CCSD Ohio 1862) (No 4,095); see also Eaton S Drone, A Treatise on the Law of Property in Intellectual Productions in Great Britain and the United States (1879), 142-144. British courts gave the corresponding statutory term a similarly generous construction. See e.g. Pamela Samuelson, Are Gardens, Synthetic DNA, Yoga Sequences, and Fashions Copyrightable?, <www.law.berkeley.edu/files/Samuelson_Oct_14_cop_subject_ matter.pdf $>$ (unavailable from original source but accessible via archive.org; copy on file with editors) (discussing British judicial interpretations).

45 See e.g. Scoville $v$ Toland, 21 F Cas 863 (CCD Ohio 1848) (No 12,553); Coffeen v Brunton,

5 F Cas 1184 (CCD Ind 1849) (No 2,946).

46 Act of 3 March 1865, ch 126, § 1, 13 Stat 540, 540 (repealed 1870).

47 Copyright Act, 1911 (UK), 1 \& 2 Geo 5, ch 46, § 21.
} 
in which established types of human creativity can be embodied to uncertainty over the availability of copyright protection seems undesirable.

To return to the example of blog posts, once society has concluded that copyright should protect literary creativity in the form of books, poems, short stories, and periodical articles, it seems sensible to protect blog posts once they come along. (Of course, a blog post might be extremely brief, and the public interest might not be served by protecting extremely short blog posts, just as it might not be desirable to protect extremely short newspaper articles. That concern, though, should be addressed not by excluding blog posts, or newspaper articles, as a type of work, from copyright's subject matter, but rather by demanding that any particular blog post or newspaper article embody protectable creativity, as discussed below. $)^{48}$

The authorial creativity involved in creating the new form of literary expression seems extremely similar to that required to create many of the older forms. Given that similarity, the public interest would not be served by a copyright statute that denied protection to extremely similar creative works simply because those works are embodied in new technological forms and instead required the legislature amend the statute to expressly include the newly enabled forms. Where authorial creativity is sufficiently similar to that of existing, protected forms, it makes sense to extend protection automatically to a new form. ${ }^{49}$

\subsubsection{The Goldilocks articulation}

This suggests that the best approach to articulating protectable subject matter is for the copyright statute to grant protection using intermediate-level statutory categories that are not overly tied to particular technologies and that have relatively capacious statutory definitions. For example, if the copyright statute protects 'pictorial works', then copyright protection would likely extend under that term to photographs made either through chemical processing of a light-sensitive carrier that has been exposed to light (as in traditional photography) or through electronic capture by an image sensor (as in

\footnotetext{
48 See section 2.2, below.

49 Of course, the legislature could act to amend the statute to deny protection to that new form if it determined that, despite the similarities, some features peculiar to the form sufficiently differentiate it from the existing protected forms such that the new form does not need or deserve copyright protection.
} 
digital photography). Similarly, protection for 'literary works' would quite easily provide protection for blog posts, even if those do not fit conventional definitions of 'books', 'newspapers', 'magazines' or even 'periodicals'.

\subsubsection{Exhaustive or illustrative articulation}

The view that the legislature should define copyright's subject matter by statute raises another question beyond the level of specificity that the legislature should use. If a copyright statute articulates its subject matter in the manner just recommended, what should the relationship be between these intermediate-level enumerated categories and the overall subject matter of copyright? A copyright statute that specifies the categories of protectable subject matter could be written in at least two ways, with very different results for what the statute does and does not protect.

In the first approach, which Paul Goldstein and Bernt Hugenholtz refer to as 'exhaustive' categorisation and which Tanya Aplin labels the 'closed list' approach, the list of categories enumerated in the copyright statute as protectable exhaustively identifies the entire universe of subject matter protectable under the law: copyright protects works in those categories and only works in those categories. The United Kingdom, Canada, and Austria are all examples of copyright systems with statutes using this approach. For example, in the United Kingdom, the Copyright, Designs and Patents Act 1988 (CDPA) § 1(1) extends protection to literary, dramatic, musical, and artistic works as well as to sound recordings, films, broadcasts, and the typographical arrangement of published editions. ${ }^{50}$ Canada protects 'every original literary, dramatic, musical and artistic work', as well as performer's performances, sound recordings, and communication signals. ${ }^{51}$ Austrian law extends protection to 'original intellectual productions in the fields of literature, music, art and cinematography'. ${ }^{52}$

50 Tanya Aplin, 'Subject Matter' in Estelle Derclaye (ed), Research Handbook on The Future of EU Copyright (Edward Elgar, 2009), 49-76.

51 Copyright Act, RSC 1985, § 5(1) (literary, dramatic, musical, and artistic works); $§ 15(1)$ (performer's performances); § 18(1) (sound recordings); § 21(1) (communication signals).

52 Federal Law on Copyright in Works of Literature and Art and on Related Rights (Austria), BGBl. No 111/1936, Art 1(1); see also Goldstein and Hugenholtz, above n 35, 195. 
By contrast, in 'illustrative' categorisation (or an 'open list' approach), the general statement of copyright's subject matter may be followed by a list of more specific categories that are identified as protected, but because the list is not exhaustive, this approach allows copyright 'protection for classes of works falling well outside recognized subject matter categories' ${ }^{53}$ France, as Aplin suggests, offers an excellent example of this approach, protecting 'all works of the mind, whatever their kind, form of expression, merit or purpose', and offering an illustrative list of categories. ${ }^{54}$ (It seems unlikely, however, that this statutory language is read literally; Thomas Edison's incandescent lightbulb clearly seems to have been a 'work of the mind', but probably not a copyrightable one.) The Berne Convention also takes this approach, requiring adhering countries to protect 'the rights of authors in their literary and artistic works', ${ }^{55}$ explaining that this phrase 'shall include every production in the literary, scientific and artistic domain, whatever may be the mode or form of its expression', ${ }^{56}$ and then providing a long but only illustrative list of examples. ${ }^{57}$

The United States technically takes the illustrative approach but practically appears to operate under an exhaustive categorisation. The US copyright statute describes the basic subject matter protected under current copyright law as 'works of authorship', ${ }^{58}$ but does not affirmatively define that term. Instead, it states that works of authorship 'include' eight specific categories listed in the statute. ${ }^{59}$ The use of the word 'include', which the statute defines as being 'illustrative and not limitative ${ }^{\prime 60}$ indicates that copyright could be recognised in works that do not fall within any expressly enumerated category, and the statute's legislative history suggests that this may have been the drafters' intent

\footnotetext{
53 Goldstein and Hugenholtz, above n 35, 195.

54 Intellectual Property Code (France), Art L112-1.

55 Berne Convention, Art 1.

56 Berne Convention, Art 2 (emphasis supplied).

57 Berne Convention, Art 2. But see Ricketson and Ginsburg, above n 34, at 409 ('[A]n unlisted work's potential status in theory as a "literary or artistic work" for the purposes of article 2(1) has meant very little, if anything, in practice ... The only mechanism provided by the Convention to achieve uniformity among Union members on [whether a new category of work is a literary or artistic work] is by a revision conference which amends article 2 so as to include the work in question, or by subsequent multilateral agreements ...').

$58 \quad 17$ USC \& 102(a).

5917 USC $\S 102(a)(1)-(8)$. The enumerated categories are literary works; musical works; dramatic works; pantomimes and choreographic works; pictorial, graphic, and sculptural works; motion pictures and other audiovisual works; sound recordings; and architectural works.

6017 USC $\S 101$ ('including').
} 
to some degree ${ }^{61}$ Nevertheless, the US Copyright Office has taken the position that the statute does not permit courts or the Copyright Office 'to create new categories of authorship', ${ }^{62}$ and I am unaware of any court decision granting copyright protection in the US to a work not found to fall within any of the statutorily enumerated categories. ${ }^{63}$

In comparing the two approaches, Aplin notes that exhaustive categorisation has the advantage of restraint that ensures that protection is not extended inappropriately to subject matter that should not be protected. (Aplin also suggests that a closed list offers the advantage of certainty of what is and is not protected, though the discussion above regarding the potential for broad construction of a statutory term such as 'book' may undercut the certainty provided even by a closed list.)

By contrast, Aplin identifies the benefits of illustrative categorisation as flexibility and completeness in protecting subject matter that may not have been expressly contemplated when the law was drafted. (Again, Aplin suggests that the open list offers the advantage of simplicity in that new works need not be shoehorned into existing categories, but while it may be possible to tell whether the work is protectable without reference to enumerated categories, to the extent the copyright statute differentiates the rights, remedies, or duration of protection by categories, shoehorning may still be required to determine exactly what copyright protection the work gets.) She notes disadvantages with each approach as well, though indicates that there are ways to minimise them. ${ }^{64}$

61 HR Rep No 94-1476 (1976), 51 ('Authors are continually finding new ways of expressing themselves, but it is impossible to foresee the forms that these new expressive methods will take. The bill does not intend either to freeze the scope of copyrightable subject matter at the present stage of communications technology or to allow unlimited expansion into areas completely outside the present congressional intent. Section 102 implies neither that that subject matter is unlimited nor that new forms of expression within that general area of subject matter would necessarily be unprotected.') (emphasis added) (as corrected by Correction of Errors in Printed House Report on S.22, 122 Cong Record No 143 (daily edition 21 September 1976) at H10727).

62 Registration of Claims to Copyright, 77 Fed Reg 37,605, 37,607 (22 June 2012).

63 See generally Reese, above n 33, 1517-1521.

64 Aplin, above n 50, 49-76. 
Perhaps the best approach is a long but closed list of numerous categories, each (as noted above) defined broadly and in technologically neutral terms. Formulating a copyright statute in this way can achieve many of the advantages of both the closed list and open list approaches to identifying which types of creations copyright law protects.

Under this approach, extending copyright to additional subject matter - such as perfume, fireworks displays, etc. - that differs substantially from the types of creations that have already been enumerated as protected would require legislative deliberation to amend copyright law by adding a new category. This would embody the restraint advantage that Aplin identifies with exhaustive categorisation, by ensuring that a new form of creative expression (such as a digital recording of a scent) or an existing but previously uncopyrightable form (such as a sporting event) would not be protected without an affirmative decision of whether protection would serve the publicinterest goals of copyright identified above.

Broad and technologically neutral definitions, though, should help ensure that new technological forms and evolutions of existing types of copyrightable creativity are covered without the need for further legislative action. As discussed in the previous section, forms of creative expression enabled by new technologies would be protected if they are sufficiently similar to existing forms of protected expression to come within an identified category. Under this approach, a copyright law that has protected novels and monographs and newspaper and magazine articles and pamphlets and broadsides as products of 'literary' creativity should have little trouble protecting blog posts. Similarly, protection for photography in the category of works of 'pictorial' creativity should extend seamlessly to digital photographs, and protection for 'sound recordings' or 'phonograms' should cover compact discs and MP3 files as easily as those terms covered 33-1/3 rpm long-playing vinyl records. This approach thus offers at least a significant portion of the flexibility advantage that Aplin identifies with illustrative categorisation, allowing in many (though likely not all) instances protection for new forms of embodying creativity even if those forms were not expressly within the contemplation of the drafters when the copyright statute was adopted. 


\subsection{Category-based exclusions from copyright}

Given the breadth with which copyright protection will be extended even under a closed list of broadly defined categories, a public interest copyright law should also expressly exclude a number of categories of works which should not receive copyright protection.

\subsubsection{Edicts of government}

A reimagined copyright system should not grant protection to '[e]dicts of government, such as judicial opinions, administrative rulings, legislative enactments, public ordinances, and similar official legal documents' ${ }^{65}$ Copyright control over government edicts has the potential to drive up the cost of and otherwise restrict access to those works. But the obligation of all citizens to obey the law, and the rights of all citizens to participate in their governance, mean that access to these edicts of government should not be restricted by copyrightbased claims of exclusivity. In addition, naturalist claims of authorial rights to attribution and integrity do not generally fit well with many of these kinds of works.

While the public interest in maximum access to these edicts of government argues for leaving these works entirely outside the scope of copyright protection, the public also has an interest in ensuring that it has access to accurate and authentic versions of government edicts. Copyright law could provide one method by which government entities can seek to ensure that those who copy and disseminate

65 US Copyright Office, Compendium II: Copyright Office Practices, § 206.01 (1984) ('Edicts of government, such as judicial opinions, administrative rulings, legislative enactments, public ordinances, and similar official legal documents are not copyrightable for reasons of public policy. This applies to such works whether they are Federal, State, or local as well as to those of foreign governments.'). See also Berne Convention Art 2(4) ('It shall be a matter for legislation in the countries of the Union to determine the protection to be granted to official texts of a legislative, administrative and legal nature, and to official translations of such texts.'). 
government edicts do so accurately. For example, the government could grant the right to reproduce legal edicts protected by copyright only on the condition that the grantee not alter the text in any way. ${ }^{66}$

But the public interest in accuracy and authenticity can likely be served by more targeted legal provisions, parallel to provisions on fraud and misrepresentation. More targeted provisions could impose penalties on those, for example, who represent to the public that a particular text is an enacted law or a rendered judicial opinion when it is not, or who negligently provide inaccurate versions of government edicts to the public. These more targeted provisions could likely address the public interest in access to accurate and authentic government information while reducing the danger that copyright control will be used to restrict access to such information.

It is not clear that this exclusion should be extended more generally to any authorial creation produced by or on behalf of a government entity. For example, one can imagine a government employee, as part of her official duties, creating a poster advertising a national park in the hope of encouraging more people to visit the park. If people find the poster beautiful, they might want to buy prints of it to hang in their homes, or postcards of it to send to friends and family. A government might decide not to grant or assert copyright protection in works produced by government employees or agents, perhaps on the ground that the public has already paid to have those works created by paying the salaries of their creators. ${ }^{67}$ But the public interest does not provide as strong a rationale for categorically excluding such works from copyright protection as it provides for excluding edicts of government.

66 See e.g. Michael Geist, 'Government of Canada Quietly Changes Its Approach to Crown Copyright' on Michael Geist, Michael Geist, (25 November 2013), <www.michaelgeist. $\mathrm{ca} / 2013 / 11 /$ crown-copyright-change/> (noting that in 2010 Canada had granted permission to reproduce government works for non-commercial purposes as long as the work was reproduced 'in the manner that it is originally published' and without 'any alterations whatsoever'); Reproduction of Federal Law Order, SI/97-5 (Canada) (allowing anyone, 'without charge or request for permission,' to reproduce federal enactments and judicial and administrative decisions 'provided due diligence is exercised in ensuring the accuracy of the materials reproduced and the reproduction is not represented as an official version'), <laws.justice.gc.ca/eng/regulations/ SI-97-5/FullText.html>.

67 See e.g. 17 USC $\S 105$ ('Copyright protection under this title is not available for any work of the United States Government ...'); HR Rep No 94-1476 (1976), 59 (noting the argument that where a work is prepared with the use of government funds, 'the public should not be required to pay a "double subsidy"'). 


\subsubsection{Subject matter protected more appropriately elsewhere}

A reimagined copyright system also should not provide protection for subject matter that would be protected more appropriately under another legal regime.$^{68}$ In particular, if a particular type of potentially copyrightable subject matter would benefit from a targeted, tailored sui generis regime of protection in order to achieve the public benefit of encouraging the production and dissemination of that type of work while imposing fewer costs (principally in restricted access and reuse) than copyright would impose, then the public as a whole should prefer the sui generis regime rather than copyright protection. In addition, shoehorning into copyright subject matter that only uneasily fits there will require courts to apply copyright doctrines and principles to situations and types of works for which they were not designed and to which they do not easily apply, and doing so may then distort those doctrines and principles in ways that could adversely affect their application to works and uses at the core of copyright protection.

This approach might exclude from protection a number of categories of works that have been the subject of much discussion as to the desirability of sui generis protection. Two of the most prominent are computer programs and industrial design. There is a substantial academic literature on the desirability of a sui generis regime to protect computer software. ${ }^{69}$ Indeed, Sam Ricketson and Jane Ginsburg relate that early international efforts were made to create a sui generis system to protect computer programs before a 'heavily pragmatic' move was made to protect them as literary works under copyright law. ${ }^{70}$ Industrial design is another product of human creativity that copyright has had difficulty dealing with. Paul

68 This principle would largely deny copyright protection to inventions protectable by patent law, because patent protection seems more appropriately tailored to inventions than copyright law. In practice, the articulation of copyrightable subject matter in the manner recommended in Part I.A.3 (this chapter), in conjunction with the articulation of patentable subject matter, should itself eliminate a great deal of the potential overlap, since many patentable inventions will not come within any of the enumerated categories of copyrightable subject matter. In addition, provisions on the scope of copyright protection will help eliminate overlap, if they make clear that copyrightable literary or pictorial representations of an invention do not provide exclusive rights to the invention itself. See e.g. Baker v Selden, 101 US 99 (1879); 17 USC $§ 102(b)$ (denying protection to any 'idea, procedure, process, system, method of operation, concept, principle, or discovery' embodied in a copyrighted work).

69 See e.g. Pamela Samuelson et al, 'A Manifesto Concerning the Legal Protection of Computer Programs' (1994) 94 Columbia Law Review 2308, 2310-2313; and works cited at note 6 therein.

70 Ricketson and Ginsburg, above n 34, §§ 8.92-8.96, 491-494. 
Goldstein has described the issue of protectability of industrial design as the most troublesome line in US copyright law. ${ }^{71}$ In some places, industrial designs are offered a separate regime of protection that could obviate the need for including them in copyright at all. ${ }^{72} \mathrm{~A}$ third candidate for exclusion on this ground is the design of clothing. While some copyright systems generally protect fashion design ${ }^{73}$ and others generally exclude it, $^{74}$ both academic investigation ${ }^{75}$ and industrysupported legislative proposals ${ }^{76}$ suggest that a sui generis system of protection that is less expansive than copyright could be sufficient to meet any public interest in protecting fashion design. If so, fashion design should be excluded from copyright protection.

\section{Standards for copyright protection}

Defining the subject matter of copyright law provides a threshold definition of which types of human creations are eligible for copyright protection, sorting among types of creativity to determine which ones can and which cannot acquire copyright. But establishing the proper subject matter of copyright should be only one element in identifying what a reimagined copyright system should protect. Not every actual creation that comes within the scope of copyright-eligible subject matter should in fact be protected by copyright. If I stand in front of a crowd and say 'That which does not kill us makes us stronger', ${ }^{77}$ a

71 Paul Goldstein, Goldstein on Copyright (Aspen Publishers, $3^{\text {rd }}$ ed, 2005 and 2015 Supplement) $\S 2.5 .3$ at $2: 67$.

72 Graeme B Dinwoodie and Mark D Janis, Trade Dress and Design Law (Aspen Publishers, 2010) 527-566.

73 Intellectual Property Code (France), Art L112-2(14) (protecting 'creations of the seasonal industries of dress and articles of fashion').

74 US Copyright Office, Compendium of US Copyright Office Practices ( $3^{\text {rd }}$ ed, 22 December 2014) $\S 924.3(\mathrm{~A})$ ('[T]he U.S. Copyright Office will not register a claim in clothing or clothing designs.').

75 See e.g. Kal Raustiala and Christopher Sprigman, 'The Piracy Paradox: Innovation and Intellectual Property in Fashion Design' (2006) 92 Virginia Law Review 1687; Kal Raustiala and Christopher Sprigman, 'The Piracy Paradox Revisited' (2009) 61 Stanford Law Review 1201. But see C Scott Hemphill and Jeannie Suk, 'The Law, Culture, and Economics of Fashion' (2009) 61 Stanford Law Review 1147; C Scott Hemphill and Jeannie Suk, 'Remix and Cultural Production' (2009) 61 Stanford Law Review 1227.

76 See e.g. Innovative Design Protection Act, S 3523, $112^{\text {th }}$ Cong (2012); Design Piracy Prohibition Act, HR 2511, 112 $2^{\text {th }}$ Cong (2011); Innovative Design Protection and Piracy Prevention Act, S 3728, $111^{\text {th }}$ Cong (2010); Design Piracy Prohibition Act, HR 2196, $111^{\text {th }}$ Cong (2009); Design Piracy Prohibition Act, S 1957, $110^{\text {th }}$ Cong (2007); Design Piracy Prohibition Act, HR 2033, $110^{\text {th }}$ Cong (2007); HR 5055, $109^{\text {th }}$ Cong (2006).

77 See Peters $v$ West, 692 F. 3 d $629\left(7^{\text {th }}\right.$ Cir, 2012). 
copyright system based on the goals identified above should probably not award me copyright protection in the nine words that I spoke. Rather, any specific creative work should have to meet certain standards in order to qualify for copyright protection. At least four possible standards would help confine copyright protection to instances in which it is likely to further the public interest: independent creation, creativity, fixation and minimum size.

\subsection{Independent creation}

Copyright laws generally impose a standard of independent creation and deny copyright to works (or elements thereof) that have been copied from someone else's work. Goldstein and Hugenholtz summarise this as a requirement that 'the work distinctively be the product of its author's intellectual efforts and not be copied from some other work or works' ${ }^{78}$ They note that common law systems generally implement this requirement using a standard of originality (the work must originate with the author), while civil law systems demand that a work be 'the author's own intellectual creation' ${ }^{79}$

The requirement that an author must have created her work herself (and the consequent principle that her copyright protects only those elements of her work that she has not copied) works in harmony with other aspects of a reimagined copyright system. In particular, excluding from copyright protection any material in an author's work that has been copied from another work helps ensure that once a work enters the public domain, it will remain there free for anyone to use, without needing to fear a plausible claim of copyright infringement from a third party who had copied the public domain work (or parts thereof) into her own copyrightable work. In addition, the requirement serves the aim of rewarding authors for their creative efforts by not rewarding them for merely copying the creativity of another author. 


\subsection{Creativity}

The issue of standards raises the recurring question whether copyright should protect only works that embody some creative contribution by their authors or whether it should also protect works that embody only the authors' labour and effort (and perhaps skill) that does not rise to the level of creativity.

A reimagined copyright law could dispense with any standard of creativity (or perhaps even labour) whatsoever, and simply grant protection to any work that falls within the articulated categories protected by the statute so long as the author claiming copyright protection has, as noted in the previous section, created the particular work herself. This would avoid the need for any real evaluation of the content of the work as part of determining its protectability, which would seem administratively simpler. However, the simplicity of such an approach must be weighed against the likelihood that many people could likely mount plausible copyright claims to entirely routine and uncreative works which in many cases would likely amount to little more than unelaborated basic building blocks of authorial expression, such as a short sequence of musical notes, very basic literary phrases or sentences, visual works consisting only of basic geometric shapes, etc. If such copyright claims are plausible in the absence of any standard for protection beyond independent creation, then such an approach would likely lead to overprotection, both because copyright protection is not needed to encourage or reward the production of such works, and because copyright protection for such basic works might hinder the creation and copyrighting of more elaborated works.

For example, if an author holds a plausible copyright in a work that consists merely of a single black stripe running horizontally across a piece of paper, that copyright claim might well inhibit other visual artists who wish to use a horizontal stripe in their works. Even if a later artist wants to use a red stripe, or a black stripe that is thinner or thicker, or more than one black stripe, she might worry that her visual work would be deemed substantially similar to the black stripe, and therefore infringing, and therefore she might not be willing to risk creating her work. The later artist might well ultimately not be liable because the copyright owner might not be able to prove that she in fact copied her stripe from the copyrighted stripe, or that her work is substantially similar to the copyrighted stripe. But the eventual 
resolution of these issues in infringement litigation would likely provide little solace ex ante to the risk-averse later artist, who might instead simply choose to avoid using a horizontal stripe in her work (and might similarly seek to avoid using other basic geometric shapes arguably protected by other copyrights). The public interest would hardly be served by a system in which many authors try to avoid using basic building blocks of their chosen expressive form, even if such a system has the administrative advantage of granting copyright protection without the need for any consideration of whether a work results from authorial creativity or labour.

Some creativity standard thus seems important as a filter for copyright protection. The law, though, should impose a relatively low standard of creativity as the threshold that a work must clear to enter the realm of copyright. Imposing any higher creativity standard would mean that judges or administrators applying the copyright statute would likely have to engage in significant qualitative evaluation of an author's work to determine whether the work is protected. It seems clear that the public would not be well served by such a system. Justice Oliver Wendell Holmes's 1903 observation that '[i]t would be a dangerous undertaking for persons trained only to the law to constitute themselves final judges of the worth of pictorial illustrations outside of the narrowest and most obvious limits' ${ }^{80}$ seems equally valid today and equally relevant to other types of creative expression beyond pictorial illustrations. At least some judges may well regard themselves as qualified to make such evaluative judgments, and indeed some judges may well be excellent critics of some forms of copyrightable expression (and indeed some judges may themselves also be authors in some of those forms). But society cannot assume that aesthetic perceptiveness will necessarily be a skill generally shared by those who serve as judges or by agency officials whose primary responsibilities are legal. And society as a whole probably would not benefit from structuring its copyright system in a way that would require staffing courts and agencies (or at least those dealing with copyright issues) only with people who have such skill. Even if it were possible to do so, it is not clear that such specialist judges or officials

80 Bleistein v Donaldson Lithographing Co, 188 US 239 (1903); see also Diane Leenheer Zimmerman, 'The Story of Bleistein v Donaldson Lithographing Company: Originality as a Vehicle for Copyright Inclusivity' in Jane C Ginsburg and Rochelle Cooper Dreyfuss, Intellectual Property Stories (Foundation Press, 2006) 77, 96-99. 
would necessarily be able to reach uniform, objective qualitative assessments of the extent to which a given work of authorship displays a high degree of authorial creativity. Any required determination of creativity - indeed, any determination of skill and judgment, or even of intellectual labour or effort - will require the judge or agency to make some at least somewhat qualitative evaluation of a work seeking copyright protection. But the public interest is better served by minimising the degree of qualitative evaluation needed. As a result, any creativity standard imposed as a requirement for copyright protection should be a relatively low one.

If copyright law imposes only a relatively low standard of creativity, questions of whether a work meets the standard will likely arise mostly with regard to what might be considered marginal works. Most authors' creations that come within copyright's subject matter will easily be judged to have substantially exceeded a low creativity requirement, because most such works will easily be found to embody much more creativity than is required.

While a relatively low creativity requirement will therefore likely filter out of copyright protection relatively few works, it may be precisely at the margins where society will benefit from demanding a modest amount of creativity in order for a work to qualify for protection. Works at the margins will be those that are not obviously and abundantly creative. Such works are more likely to be close to the bone in terms of authorial expression, and may often be just a relatively unarticulated presentation or combination of some of the basic building blocks of their type of expressive form. For example, in terms of graphic works, this might involve a standard size, white business envelope with a thick black stripe running across the width of the upper half of the envelope. ${ }^{81}$ In a system designed to achieve the goals outlined above, the argument for protecting such works seems quite weak. Given how little creativity is needed to create these works, copyright protection is likely not needed as an incentive to encourage authors to create and disseminate them (in the instrumentalist view) and the person who creates these works may well not deserve to be

81 See e.g. Magic Marketing $v$ Mailing Services of Pittsburgh, 634 F Supp 769 (WDPa 1986) (denying claim to copyright in envelope with such a stripe that contained the words 'Priority Message: Contents Require Immediate Attention'); Gorman, Ginsburg, and Reese, above n 25, 85 (reproducing envelopes denied copyright as insufficiently minimally creative). 
recognised as an 'author' entitled to protection (in the naturalist view). And in any event, protecting such works does not seem justified given the likely cost of protection. Works that do not even show a very low degree of creativity likely elaborate very little on the basic building blocks of expression, which means that many other authors will likely be using those same building blocks. Allowing a copyright in the uncreative work will present the possibility that the copyright owner could at least bring plausible infringement suits against other, more creative, authors. Society seems better served if every author can use the basic building blocks of copyrightable expressive forms as the raw material to produce her own creative articulations and combinations of those building blocks.

This is not to say that there will not be difficult cases. For example, Kazimir Malevich's 1915 Suprematist painting Black Square, a painted black square surrounded by a margin of white, may have marked a dramatic challenge to the conventions of painting at the time, but viewing the final painting as sufficiently creative for copyright protection raises the danger that copyright in the painting might restrict other artists' ability to use as basic a geometric form as the square. But for any standard, there will be instances close to the line where reasonable minds might differ in the determination regarding on which side of the line the work falls. To the extent that copyright needs to impose some standard in order to deny protection to overly minimal works, most of the social benefit in having the standard derives from excluding material that has very little creativity. As a result, society can get that benefit by setting a relatively low creativity standard, and that standard means that the risk of false negatives should principally impact only relatively uncreative works.

A creativity standard, even a relatively low one, seems likely to have the most impact on one particular type of authorial work: collections of factual information. ${ }^{82}$ Because facts themselves are generally not protectable by copyright, the only opportunity for creativity in such works is in the collection and presentation of the facts. ${ }^{83}$ This usually means that an author must show that she exercised creativity

82 See Sam Ricketson, 'Common Law Approaches to the Requirement of Originality' in Catherine W Ng, Lionel Bentley and Giuseppina D'Agostino, The Common Law of Intellectual Property: Essays in Honour of Professor David Vaver (Hart Publishing, 2010) 233-251.

83 See e.g. Feist Publications Inc v Rural Telephone Service, 499 US 340 (1991). 
in selecting which facts to include, or in arranging those facts in the collection, or both. In many instances, the author will find it difficult to satisfy this creativity standard. Often, for example, the author attempts to present a comprehensive collection of the relevant facts, and so engages in no real selection at all, let alone a creative one. And often the facts are arranged in an entirely conventional and uncreative manner, such as alphabetically, chronologically or ordinally. For these collections of information, then, imposing a creativity standard would often mean denying copyright protection. By contrast, most collections of information likely could meet a copyright standard that requires only that the collection reflect the author's labour and effort (perhaps even intellectual effort), since in most instances the author will have expended such labour in producing even the non-creative collection. Indeed, some collections of information could likely meet a standard that demands that the author used skill to produce the work, even if skill is more than mere effort but less than creativity.

To the extent that a relatively low creativity standard would have its greatest impact on collections of information and would likely disqualify many of those collections from protection, such collections might generally be more appropriately protected, if at all, by a legal regime other than copyright. As discussed above, the goals of a reimagined copyright system revolve around the production and availability of creative works. Collections of factual information that require an investment of labour to produce, but that are not creative, may need some legal protection in order to prevent free-riding copying by third parties that would too greatly undermine the incentive for the initial producer to invest in collecting and organising the information in the first place. That specific problem, though, could be addressed by a legal regime that more directly targets the problem and that tailors the requirements that such collections must meet to be protected, as well as the rights and remedies that a protected product receives.

For example, in the European Union, the Database Directive ${ }^{84}$ requires member nations to protect even non-creatively selected or arranged collections of information if the compiler has made a substantial investment in obtaining, verifying or presenting the contents of

84 Directive 96/9/EC of the European Parliament and of the Council of 11 March 1996 on the legal protection of databases [1996] OJ L 77, 20-28 ('EC Database Directive'). 
the collection. ${ }^{85}$ But it provides different rights (the right to prevent extraction or reutilisation of all or a substantial part of the contents of the collection $)^{86}$ and limitations, ${ }^{87}$ as well as a much shorter nominal term of protection ( 15 years from when completed, or, if made public during that term, 15 years from when made public). ${ }^{88}$ In US law, unfair competition law provides a cause of action for misappropriation where:

(i) the plaintiff generates or collects information at some cost or expense; (ii) the value of the information is highly time-sensitive; (iii) the defendant's use of the information constitutes free-riding on the plaintiff's costly efforts to generate or collect it; (iv) the defendant's use of the information is in direct competition with a product or service offered by the plaintiff; ( $v$ ) the ability of other parties to freeride on the efforts of the plaintiff would so reduce the incentive to produce the product or service that its existence or quality would be substantially threatened. ${ }^{89}$

While many producers of information collections would not likely to be able to bring misappropriation claims because the information they present is not 'highly time-sensitive', the elements of this claim offer a model for how a tailored, non-copyright regime protecting such collections against unfair free riding could be structured, if such protection were deemed necessary.

Protecting collections of information through a tailored, non-copyright regime would be better than having the tail of preventing free riding non-creative collections of information wag the dog of not protecting uncreative expressive works in order to keep basic building blocks of creativity free for all to use. If the most substantial concern about imposing a relatively low creativity standard involves the effects of that standard on non-creative collections of information, those effects would be better addressed by whatever non-copyright protection might be justified for such collections, rather than by lowering the standard to be applied to all works within copyright's subject matter.

\footnotetext{
85 EC Database Directive, Art 7(1).

86 EC Database Directive, Art 7(1).

87 EC Database Directive, Art 9.

88 EC Database Directive, Art 10.

89 National Basketball Assn v Motorola, 105 F 3d 841, 853 (2 ${ }^{\text {nd }}$ Cir, 1997).
} 


\subsection{Fixation}

Another possible requirement that copyright law might impose for a copyright-eligible creation to obtain protection is that the creation be fixed in some tangible medium in order to be protected.

A fixation requirement helps to preserve the cultural record, and encouraging the creation of that cultural record is a principal purpose of a reimagined copyright law. Once a work is fixed, the likelihood that some embodiment of that work will survive and be available to future audiences increases dramatically (though the survival of at least one embodiment of any work is, of course, in no way guaranteed).$^{90}$ Of course, fixation of copyrightable creativity doesn't preserve the cultural record perfectly. For some types of works, a fixation will not convey the full scope of the author's creativity. A film of a stage performance of a play cannot capture the entirety of the live performance, and notation of a choreographic work obviously captures even less of the dance as performed. But a recording of a performed work will still give future audiences, creators, and performers more information about the author's created work then they will have if the work is never fixed in any form.

A fixation requirement also serves to make copyright law more administrable, by providing evidence of the existence and content of the author's creative product. This evidence is obviously crucial when the author of the work claims that a defendant has infringed the work and a court must determine whether the work meets the standards for protection and whether the defendant has indeed infringed on any of the expression in the work.

While the goals of a reimagined copyright system thus support including a requirement that works be fixed in order to be protected, the requirement need not be particularly onerous. It should be technologically neutral so that any form of fixation will qualify. It should perhaps not focus on whether the fixation was made with or without the author's consent - if an audience member tapes a lecturer's impromptu address without permission (and perhaps in defiance of an express prohibition on recording), that should not stop the lecturer

90 See e.g. R Anthony Reese, 'What Copyright Owes the Future' (2012) 50 Houston Law Review 287, 296-306. 
from bringing a claim of copyright infringement and satisfying the fixation requirement by means of the audience member's illicit recording. ${ }^{91}$

While fixation should be a requirement for any particular item of copyright-eligible subject matter to qualify for protection under a reimagined copyright law, the public interest might still be served by granting creators and performers of unfixed works more limited protection, either as part of copyright law or as a separate scheme, against unauthorised fixation of their works. Such protection should be tailored to the particular aims of protecting those who create and perform unfixed works against having their works fixed without their consent.

\subsection{Size}

Already in the mid-1960s Benjamin Kaplan had given some attention to the question of whether some products of creative expression were too small to be protected by copyright:

We can, I think, conclude that to make the copyright turnstile revolve, the author should have to deposit more than a penny in the box ... Surely there is danger in trying to fence off small quanta of words or other collocations; these pass quickly into the idiom; to allow them copyright, particularly if aided by a doctrine of 'unconscious' plagiarism, could set up untoward barriers to expression. ${ }^{92}$

More recently, Justin Hughes has written about the problems that may come from recognising copyright protection for quantitatively small amounts of original expression within the scope of copyright. ${ }^{93}$ Among other problems, many copyright doctrines are based on a conception of a more substantial 'work' as the basic subject matter of copyright, and may be distorted if they are applied to very small units of expression, which Hughes labels 'microworks' ${ }^{94}$ Protecting a small unit of expression as part of a larger work creates fewer problems

91 This would be a departure from, for example, current US law, which requires that a work be fixed 'by or under the authority of the author' in order to qualify for copyright protection. 17 USC $\S 101$ ('fixed').

92 Kaplan, above n 36, 46.

93 Justin Hughes, 'Size Matters (Or Should) in Copyright Law' (2005-2006) 75 Fordham Law Review 575.

94 Ibid. See also Garcia v Google Inc, 786 F 3d 733, 742-743 ( $9^{\text {th }}$ Cir, 2015) (en banc). 
because, for instance, claims of infringement by copying the small portion of the larger work can be more appropriately handled through considerations of de minimis, substantial similarity, scènes à faire, and fair use or fair dealing. But if, for example, a single number (such as a price or a parts number) or a phrase of only a few words (or even a short collection of words and other characters that make up a URL) is itself a copyrightable work, then copying the number or phrase will be hard to excuse as de minimis or insubstantial.

The difficulty, of course, is formulating any absolute rule as to the minimal size necessary for a creative expression to qualify for copyright protection. At the very least, this seems likely to vary a good deal with the type of creation involved. And, as Hughes suggests, it may involve consideration of a number of factors such as independent economic value, artistic viability, separate dissemination, audience perception, and compositional integrity. ${ }^{95}$

A useful approach for dealing with this issue may be to specify that copyright attaches to a creation within the subject matter of protection only when that creation contains an appreciable amount of the creator's original expression. The development of specific tests and principles for applying this quantitative requirement would rest, at least as an initial matter, with administrative and judicial authorities in the application of the requirement to particular instances in which claims to copyright are made in very small units of expression.

In the United States, the Copyright Office interprets the current statute to mean that a work must contain 'at least a minimum amount of creative authorship that is original to the author' in order to be copyrightable. ${ }^{96}$ But while courts may have the authority under current law to interpret the statute in this way, the fact that any such requirement is at best implicit seems to have led at least some courts

95 Hughes, above n 93, 622-635. See also Paul Goldstein, 'What Is a Copyrighted Work? Why Does It Matter?' (2011) 58 UCLA Law Review 1175 (arguing that looking to authorial intent, particularly as reflected in registration records, can often be relied on to counter copyright owners' litigation incentives 'to skew the calibration of his work toward a size more granular than principle, law, or practice might reasonably condone').

96 US Copyright Office, above n 74, ( $3^{\text {rd }}$ ed) $\S 309$. While this interpretation thus likely plays a role in administrative decisions whether to register claims of copyright, it appears to have played little role in judicial interpretation of the statute. 
astray. ${ }^{97}$ Making the requirement explicit, even if at a fairly high level of generality, may therefore be an improvement in how copyright law is understood and applied.

As with the creativity requirement, for the vast majority of copyrightable works - books, articles, musical compositions, sound recordings, plays, films, paintings, photographs, sculptures, dances, etc. - where the public would generally want to make copyright relatively easily available, this requirement should pose no hurdle whatsoever to obtaining copyright protection. Indeed, for most copyrightable works, any challenge that the work does not meet the appreciable amount requirement should take a court or administrative agency no more than a couple of sentences to reject. But for claims close to the line, the requirement would serve the public interest by making clear that the law does not recognise an independent copyright in 'microworks' that fall below the threshold of an appreciable amount of original expression and by making it easier to eliminate threatening claims of infringement against those who copy only such small units of expression.

\section{Conclusion}

The aims of a copyright system redesigned in the public interest do not dictate a particular definition of copyrightable subject matter or a necessary set of standards for protection. In imagining a copyright law designed from scratch, the law's subject matter and standards for protection would not necessarily look substantially different from some of the current provisions on those issues in various copyright systems, although perhaps no single existing system currently has all of the features recommended in this chapter. The identified goals of a reimagined copyright system argue that the subject matter of copyright should be legislatively articulated in the form of intermediate-level, technologically neutral categories, and that any new categories should be recognised as copyrightable only by legislative decision. In addition, creative productions that can be more appropriately protected by more tailored forms of protection (such as computer programs, industrial design, and non-creative compilations

97 See e.g. CDN Inc v Kapes, $197 \mathrm{~F} 3 \mathrm{~d} 1256\left(9^{\text {th }}\right.$ Cir, 1999) (holding plaintiff's estimates of prices of collectible coins to be copyrightable works); Hughes, above n 93, 583-600. 
of factual information) should be excluded from copyright protection. Once copyright's subject matter has been defined, the public interest would be best served by protecting only works within that subject matter that are independently created, fixed, and minimally creative, and that contain an appreciable amount of authorial expression. To the extent that these identified features do not depart significantly from the way copyright law currently operates, addressing the current challenges to copyright law identified in Chapter 1 will likely require more substantial changes to other aspects of copyright law, many of which are suggested in the other chapters in this volume. 
This text is taken from What if we could reimagine copyright?, edited by Rebecca Giblin and Kimberlee Weatherall, published 2017 by ANU Press, The Australian National University, Canberra, Australia. 